\title{
Factors associated with glycemic control in people with diabetes at the Family Health Strategy in Pernambuco*
}

\author{
Fatores associados ao controle glicêmico em pessoas com diabetes \\ na Estratégia Saúde da Família em Pernambuco \\ Factores asociados con el control glucémico en personas con diabetes \\ en la Estrategia Salud de la Familia en Pernambuco
}

Rodrigo Fonseca Lima ${ }^{1}$, Annick Fontbonne ${ }^{2}$, Eduardo Maia Freese de Carvalho' ${ }^{1}$, Ulisses Ramos Montarroyos ${ }^{3}$, Maria Nelly Sobreira de Carvalho Barreto ${ }^{1}$, Eduarda Ângela Pessoa Cesse ${ }^{1}$

How to cite this article:

Lima RF, Fontbonne A, Carvalho EMF, Montarroyos UR, Barreto MNSC, Cesse EAP. Factors associated with glycemic control in people with diabetes at the Family Health Strategy in Pernambuco. Rev Esc Enferm USP. 2016;50(6):937-944. DOI: http://dx.doi.org/10.1590/S0080-623420160000700009

* Extracted from the dissertation "Fatores associados ao controle glicêmico inadequado em diabéticos tipo 2 cadastrados na Estratégia Saúde da Família em Pernambuco", Centro de Pesquisas Aggeu Magalhães, Fundação Oswaldo Cruz, 2013.

${ }^{1}$ Fundação Oswaldo Cruz, Centro de Pesquisa Aggeu Magalhães, Departamento de Saúde Coletiva, Recife, PE, Brazil.

${ }^{2}$ Institut de Recherche Pour Le Développement, Montpellier, France.

${ }^{3}$ Universidade de Pernambuco, Instituto de Ciências Biológicas, Recife, PE, Brazil.

\begin{abstract}
Objective: Identifying factors associated with glycemic control in people with type 2 Diabetes Mellitus (DM) registered in the Family Health Strategy (FHS) in Pernambuco, Brazil. Method: Associations between glycemic control (glycosylated hemoglobin A lower or equal to $7 \%$ ) presented by people with DM and variables related to sociodemographic conditions, lifestyle, characteristics of diabetes, treatment and follow-up of patients by health services were investigated by multiple regression. Results: More than $65 \%$ of the participants presented inadequate glycemic control, especially those with lower age, longer illness duration, more annual contacts with FHS and complex therapeutic regimen. People with DM without referrals to specialists presented greater glycemic control. Associations with education level and obesity did not remain significant in the multivariate model. Conclusion: The evolution of diabetes hinders adequate control, however, attention to younger people with DM and referrals to specialists are factors that can improve glycemic control.
\end{abstract}

DESCRIPTORS

Diabetes Mellitus Type 2; Primary Health Care; Hemoglobin A, Glycosylated; Family Health Strategy. 


\section{INTRODUCTION}

During the last century, changes in the epidemiological profile of the population have been observed resulting from the process of epidemiological transition marked by an increase in Chronic Non-communicable Diseases (CNCD) ${ }^{(1)}$, among them Diabetes Mellitus (DM).

In 2010, there were 285 million adults (20-79 years) with DM, $6.4 \%$ in terms of worldwide prevalence ${ }^{(2)}$. In Brazil, according to VIGITEL (Vigilância de Fatores de Risco e Proteção para Doenças Crônicas por Inquérito Telefônico Telephone-based Surveillance of Risk and Protective Factors for Chronic Diseases) research under the Ministry of Health, the percentage of adults who reported having a diagnosis of DM in considering Brazilian capitals and the Federal District in 2013, corresponded to 6.9\%. For the Northeast and the capital of Pernambuco, the percentage was $6.3 \%$ and $6.1 \%$, respectively ${ }^{(3)}$.

For the effective control of DM, in addition to evaluating blood pressure, lipid levels and aspects related to physical activity and diet, it is essential that glycemic values are constantly evaluated, since they reflect the adequacy and effectiveness of the current therapeutic plan. Among the measurements for evaluating glycemic control, glycosylated hemoglobin A (hemoglobin A1c) stands out as being considered the standard for long-term evaluation of glycemic control ${ }^{(4)}$.

As important as the data on glycemic control are the factors that can potentially influence them, so that knowledge of these aspects allows health interventions to be adapted, possibly resulting in the improved clinical condition of people with $\mathrm{DM}^{(5)}$. Few studies on this aspect are available in Brazil, and to the authors' knowledge, none have been carried out on a representative sample of people with diabetes in primary care. In this context, this article aims to identify the factors associated with glycemic control presented by people with type $2 \mathrm{DM}$ enrolled in the Family Health Strategy (FHS), as selected to represent this population in the state of Pernambuco, Brazil.

\section{METHOD}

This is a quantitative sectional study. The data considered came from the SERVIDIAH study (Evaluation of Health Care Services for Diabetics and Hypertensives within the Family Health Program), conducted between November 2009 and December 2010, with a probabilistic sample of people with type $2 \mathrm{DM}$ registered at the FHS in the state of Pernambuco, Brazil ${ }^{(6)}$.

The sample design of the SERVIDIAH study was conceived in such a way as to allow representativeness of the municipalities of Pernambuco according to their size, with large municipalities (Recife, Caruaru and Petrolina) chosen by the representativeness criterion, and 16 medium-sized and 16 small-size municipalities randomly selected by draw. Family Health teams were drawn in each municipality based on the ratio of the total of the teams operating in the state of Pernambuco in August 2008, according to the last report of the National Registry of Health Facilities (Cadastro Nacional de Estabelecimentos de Saúde - CNES). Fifteen percent (15\%) of the total Family Health teams of the municipalities were randomly drawn in proportion to the population size, and another systematic draw of between 3 and 6 was carried out for each of the teams (depending on the size of the municipality) of people with DM (Inclusion criterion of age being greater than or equal to 20 years), based on the manual registry of Community Health Agents (CHA), thus totaling 822 participants. This process did not require estimating the population or the number of people with DM in the participating municipalities in order to carry out the draw. Of the total number of interviewees in the SERVIDIAH study, this article only considered the data of participants with valid results of hemoglobin A1c, totaling a sample of 787 people.

Data were collected by field researchers previously trained for interviewing. A structured questionnaire specifically designed by the researchers for this study was used, containing variables related to the history of the chronic condition and its follow-up by the FHS, socioeconomic indicators, lifestyle, healthcare expenses, complications, anthropometric measurements (weight, height, waist and hip circumferences), blood pressure, and hemoglobin A1c levels, among others. Hemoglobin A1c levels were performed on a capillary blood sample by a portable device which provided the result within a few minutess (in2it ${ }^{\circledR}$, by Bio-Rad).

After being informed about the objectives and procedures of the study, as well as signing the Clear and Informed Consent Form, participants were interviewed at home or in the FHS team's room/office. The SERVIDIAH study was approved by the Research Ethics Committee of the Aggeu Magalhães Research Center - CEP/CPqAM (registration number 43/2008) - and the National Commission of Ethics in Research - CONEP (Opinion no. 889/2008).

The dependent variable corresponded to glycemic control, being categorized according to the Brazilian Society of Diabetes $^{(4)}$, so that participants with hemoglobin A1c lower than $7 \%$ were considered people with DM with adequate glycemic control, and those with hemoglobin A1c greater than or equal to $7 \%$ were people with inadequate glycemic control.

The explanatory variables involved socioeconomic and demographic characteristics, basic health actions (follow-up/ access to treatment), aspects related to the effects/control produced by care such as drug treatment, modifiable risk factors (lifestyle) and clinical characteristics. Among the modifiable risk factors, leisure physical activity was categorized as "yes" or "no" (sedentary). Among the clinical characteristics, the complications resulting from DM considered were: complications in the eyes (questioned as eye complication confirmed by professional); complications in the kidneys (questioned as a malfunction of the kidneys due to DM); cardiovascular diseases (questioned as heart problem due to $\mathrm{DM}$ ); persistent sexual problems (only questioned for men); neuropathy (questioned as unbearable and permanent pain/ itchiness in the lower limbs).

In addition, anthropometric measurements and blood pressure were also considered. Weight was measured using a Tanita BC553 digital scale (Tanita Corporation, Tokyo, 
Japan), with precision of 0.1 kilogram. Height was measured with a portable stadiometer (Alturaexata, Belo Horizonte), with an accuracy of 1 millimeter. Systolic and diastolic blood pressures were measured with an Omron HEM-650 electronic pulse tensiometer (Omron Healthcare Inc., Kyoto, Japan) three times during the interview, with the person sitting for at least 10 minutes prior to measuring, and statistical analyzes were performed with the average of the three values.

Categorical variables were described by absolute and relative frequency calculations, and continuous variables were reported by mean ( \pm standard deviation). Chi-square test and Fisher's exact test were adopted for testing association of categorical variables, when necessary. Student's t-test was used for the continuous variables. In order to measure the effect of the independent variables on the analyzed outcome, a multiple logistic regression model was used with a robust estimate of variance, with Odds Ratio (OR) being the analyzed effect measure (with its respective confidence intervals of $95 \%$ ). A forward multivariate analysis was implemented having a significance of up to $20 \%(\mathrm{p}<0.20)$ in the univariate analysis as input criterion, and significance of up to $10 \%$ $(p<0.10)$ as output criterion. Data analysis was performed using $\mathrm{R}$ statistical software, version 2.13.1., and using a 5\% significance level as reference.

\section{RESULTS}

Of the 787 participants selected for the study, $68.2 \%$ were female and the mean age was $61.1( \pm 13.1)$ years. Regarding socioeconomic level, $85.5 \%$ were illiterate or had incomplete elementary education, the majority were retired (59.8\%), and $31.9 \%$ had income below a minimum wage. According to the lifestyle, $29.7 \%$ practiced leisurely physical activity, $69.4 \%$ had a healthy diet and $12.8 \%$ were smokers (Table 1 ).

Of the total, 242 people with DM were classified as controlled regarding glycemic level (Hemoglobin A1c < 7\%), which corresponds to a prevalence of 30.7\% (CI 95\%: 27.5$34.0 \%$ ); Hemoglobin A1c mean was $8.7 \% \pm 2.4 \%$.

With respect to sociodemographic and lifestyle variables (Table 1), it was shown that inadequate glycemic control was more frequent as to the duration of increased diabetes. In addition, the mean age of those with DM with inadequate control was lower compared to those with well-controlled DM. There was a tendency for better adequacy of glycemic control as the educational level increased, with significant OR for people with DM who completed high school education or higher. The risk of inadequate control was significantly higher in the category of workers without income (housewives and students). There were no significant associations between glycemic control and lifestyle, gender or income.

Table 1 - Association of inadequate glycemic control according to sociodemographic variables and lifestyle - Recife, PE, Brazil, $2009-2010$.

\begin{tabular}{|c|c|c|c|c|c|}
\hline \multirow[b]{2}{*}{ Characteristics } & \multirow[b]{2}{*}{ Total sample } & \multicolumn{2}{|c|}{ Glycemic Control } & \multirow[b]{2}{*}{ OR (CI 95\%): } & \multirow[b]{2}{*}{$p$-value } \\
\hline & & $\begin{array}{l}\text { Inadequate } \\
(\mathrm{A} 1 \mathrm{c} \geq 7 \%)\end{array}$ & $\begin{array}{c}\text { Adequate } \\
(\text { A1c }<7 \%)\end{array}$ & & \\
\hline Duration of illness & $8.6 \pm 7.5$ & $9.5 \pm 7.8$ & $6.5 \pm 6.3$ & $1.37 *(1.20-1.56)$ & $<0.001$ \\
\hline \multicolumn{6}{|l|}{ Duration of illness } \\
\hline$<5$ years & $286(38.3 \%)$ & $171(59.8 \%)$ & $115(40.2 \%)$ & Reference & - \\
\hline From 5 to 9 years & $174(23.3 \%)$ & $128(73.6 \%)$ & $46(26.4 \%)$ & $1.87(1.23-2.86)$ & 0.003 \\
\hline 10 years or longer & $286(38.3 \%)$ & $221(77.3 \%)$ & $65(22.7 \%)$ & $2.27(1.45-3.33)$ & $<0.001$ \\
\hline
\end{tabular}

\section{Sociodemographic}

Gender

\begin{tabular}{|c|c|c|c|c|c|}
\hline Male & $250(31.8 \%)$ & $169(67.6 \%)$ & $81(32.4 \%)$ & Reference & - \\
\hline Female & $537(68.2 \%)$ & $376(70.0 \%)$ & $161(30.0 \%)$ & $1.12(0.80-1.54)$ & 0.494 \\
\hline Age (in years) & $61.1 \pm 13.1$ & $60.4 \pm 12.8$ & $62.6 \pm 13.6$ & $0.93 *(0.88-0.99)$ & 0.029 \\
\hline \multicolumn{6}{|l|}{ Age group } \\
\hline$<45$ & $83(10.6 \%)$ & $58(69.9 \%)$ & $25(30.1 \%)$ & Reference & - \\
\hline $45-59$ & $263(33.4 \%)$ & $191(72.6 \%)$ & $72(27.4 \%)$ & $1.15(0.67-1.96)$ & 0.628 \\
\hline $60-74$ & $333(42.3 \%)$ & $231(69.4 \%)$ & $102(30.6 \%)$ & $0.98(0.58-1.64)$ & 0.928 \\
\hline$\geq 75$ & $108(13.7 \%)$ & $65(60.2 \%)$ & $43(39.8 \%)$ & $0.65(0.36-1.19)$ & 0.167 \\
\hline \multicolumn{6}{|l|}{ Education level } \\
\hline Illiterate & $300(38.1 \%)$ & $218(72.7 \%)$ & $82(27.3 \%)$ & Reference & - \\
\hline Incomplete primary education & $373(47.4 \%)$ & $254(68.1 \%)$ & $119(31.9 \%)$ & $0.80(0.57-1.12)$ & 0.198 \\
\hline Complete primary education & $52(6.6 \%)$ & $36(69.2 \%)$ & $16(30.8 \%)$ & $0.85(0.45-1.61)$ & 0.610 \\
\hline Secondary education or higher & $62(7.9 \%)$ & $37(59.7 \%)$ & $25(40.3 \%)$ & $0.55(0.31-0.98)$ & 0.043 \\
\hline
\end{tabular}




\begin{tabular}{|c|c|c|c|c|c|}
\hline \multirow[b]{2}{*}{ Characteristics } & \multirow[b]{2}{*}{ Total sample } & \multicolumn{2}{|c|}{ Glycemic Control } & \multirow[b]{2}{*}{ OR (CI 95\%): } & \multirow[b]{2}{*}{$p$-value } \\
\hline & & $\begin{array}{l}\text { Inadequate } \\
\text { (A1c } \geq 7 \% \text { ) }\end{array}$ & $\begin{array}{c}\text { Adequate } \\
\text { (A1c }<7 \%)\end{array}$ & & \\
\hline \multicolumn{6}{|l|}{ Occupation } \\
\hline Retired/Pensioner/Disabled assistance & $468(59.8 \%)$ & $312(66.7 \%)$ & $156(33.3 \%)$ & Reference & - \\
\hline Working & $157(20.0 \%)$ & $113(72.0 \%)$ & $44(28.0 \%)$ & $1.28(0.86-1.91)$ & 0.218 \\
\hline Unemployed & $30(3.8 \%)$ & $21(70.0 \%)$ & $9(30.0 \%)$ & $1.17(0.52-2.61)$ & 0.707 \\
\hline Housewife/student & $128(16.4 \%)$ & $98(76.6 \%)$ & $30(23.4 \%)$ & $1.63(1.03-2.57)$ & 0.033 \\
\hline \multicolumn{6}{|l|}{ Family income } \\
\hline$<1 \mathrm{MW}$ & $233(31.9 \%)$ & $162(69.5 \%)$ & $71(30.5 \%)$ & Reference & - \\
\hline$\geq 1 \mathrm{MW}$ & $497(68.1 \%)$ & $342(68.8 \%)$ & $155(31.2 \%)$ & $0.97(0.69-1.35)$ & 0.846 \\
\hline \multicolumn{6}{|l|}{ Lifestyle } \\
\hline \multicolumn{6}{|l|}{ Practices leisurely physical activity } \\
\hline Yes & $231(29.7 \%)$ & $153(66.2 \%)$ & $78(33.8 \%)$ & Reference & - \\
\hline No & $546(70.7 \%)$ & $383(70.1 \%)$ & $163(29.9 \%)$ & $1.20(0.86-1.67)$ & 0.281 \\
\hline \multicolumn{6}{|l|}{ Adopts a healthy diet } \\
\hline Yes & $538(69.4 \%)$ & 368 (68.4\%) & $170(31.6 \%)$ & Reference & - \\
\hline No & 237 (30.6\%) & 169 (71.3\%) & $68(28.7 \%)$ & $1.15(0.82-1.61)$ & 0.419 \\
\hline \multicolumn{6}{|l|}{ Smokes } \\
\hline Currently a smoker & $101(12.8 \%)$ & $73(62.3 \%)$ & $28(37.7 \%)$ & Reference & - \\
\hline Quit smoking & 322 (40.9\%) & $218(67.7 \%)$ & $104(32.3 \%)$ & $0.81(0.49-1.31)$ & 0.387 \\
\hline Never smoked & $364(46.2 \%)$ & $254(69.8 \%)$ & $110(30.2 \%)$ & $0.88(0.54-1.45)$ & 0.627 \\
\hline
\end{tabular}

* Increased chance at every increase of 5 years.

Data reported as mean \pm SD or N (\%). A1c: glycosylated hemoglobin A; CI: Confidence Interval; MW: Minimum Wage; OR: Odds Ratio.

T-test $<0.05$ for continuous variables and $\chi^{2}$ test $<0.05$ for categorical variables.

Regarding clinical aspects, $73.6 \%$ were overweight or obese, and $39.1 \%$ of the respondents had at least two complications due to DM (Table 2).

In relation to follow-up, treatment and health status variables (Table 2), inadequate glycemic control appeared more frequently among people with DM with normal weight who reported having three or more complications of the disease, and those non-referred to endocrinologist or cardiologist in the last 12 months. Inadequate glycemic control was also more frequent as drug treatment became more complex and less frequent when the user had no contact with the FHS in the past 12 months.

Table 2 - Association of glycemic control according to the anthropometric and clinical aspects, drug monitoring and treatment characteristics - Recife, PE, Brazil, 2009-2010.

\begin{tabular}{|c|c|c|c|c|c|}
\hline \multirow[b]{2}{*}{ Characteristic } & \multirow[b]{2}{*}{ Total sample } & \multicolumn{2}{|c|}{ Glycemic Control } & \multirow[b]{2}{*}{ OR (CI 95\%): } & \multirow[b]{2}{*}{$p$-value } \\
\hline & & $\begin{array}{l}\text { Inadequate } \\
\text { (A1c } \geq 7 \%)\end{array}$ & $\begin{array}{c}\text { Adequate } \\
(\mathrm{A} 1 \mathrm{c}<7 \%)\end{array}$ & & \\
\hline \multicolumn{6}{|c|}{ Anthropometric and clinical aspects } \\
\hline $\mathrm{BMI}\left(\mathrm{Kg} / \mathrm{m}^{2}\right)$ & $28.4 \pm 5.3$ & $28.2 \pm 5.3$ & $29.0 \pm 5.2$ & $0.97(0.94-1.00)$ & 0.084 \\
\hline \multicolumn{6}{|l|}{ Nutritional state } \\
\hline Normal & $188(26.4 \%)$ & $142(75.5 \%)$ & $46(24.5 \%)$ & Reference & - \\
\hline Overweight & $282(39.6 \%)$ & $191(67.7 \%)$ & $91(32.3 \%)$ & $0.68(0.45-1.03)$ & 0.069 \\
\hline Obese & $242(34.0 \%)$ & $160(66.1 \%)$ & $82(33.9 \%)$ & $0.63(0.41-0.97)$ & 0.035 \\
\hline \multicolumn{6}{|l|}{ Complications due to DM } \\
\hline None & $149(21.2 \%)$ & $103(69.1 \%)$ & $46(30.9 \%)$ & Reference & - \\
\hline 1 & $279(39.6 \%)$ & $182(65.2 \%)$ & $97(34.8 \%)$ & $0.84(0.55-1.28)$ & 0.416 \\
\hline 2 & $182(25.8 \%)$ & $126(69.2 \%)$ & $56(30.8 \%)$ & $1.00(0.63-1.61)$ & 0.984 \\
\hline$\geq 3$ & $94(13.3 \%)$ & $76(80.9 \%)$ & $18(19.1 \%)$ & $1.87(1.02-3.57)$ & 0.045 \\
\hline
\end{tabular}




\begin{tabular}{|c|c|c|c|c|c|}
\hline \multirow[b]{2}{*}{ Characteristic } & \multirow[b]{2}{*}{ Total sample } & \multicolumn{2}{|c|}{ Glycemic Control } & \multirow[b]{2}{*}{ OR (CI 95\%): } & \multirow[b]{2}{*}{$p$-value } \\
\hline & & $\begin{array}{l}\text { Inadequate } \\
(\mathrm{A} 1 \mathrm{c} \geq 7 \%)\end{array}$ & $\begin{array}{c}\text { Adequate } \\
(\text { A1c }<7 \%)\end{array}$ & & \\
\hline \multicolumn{6}{|l|}{ Characteristics of monitoring* } \\
\hline \multicolumn{6}{|l|}{ Number of contacts with the FHS } \\
\hline$\geq 4$ times & $281(37.7 \%)$ & $206(73.3 \%)$ & $75(26.7 \%)$ & Reference & - \\
\hline $1-3$ times & $262(35.1 \%)$ & $183(69.9 \%)$ & $79(30.1 \%)$ & $0.84(0.58-1.22)$ & 0.371 \\
\hline None & $203(27.2 \%)$ & $125(61.6 \%)$ & $78(38.4 \%)$ & $0.58(0.39-0.86)$ & 0.006 \\
\hline \multicolumn{6}{|l|}{ Referral to endocrinologists } \\
\hline Yes & $133(17.0 \%)$ & $81(60.9 \%)$ & $52(39.1 \%)$ & Reference & - \\
\hline No & $649(83.0 \%)$ & $460(70.9 \%)$ & $189(29.1 \%)$ & $1.56(1.06-2.32)$ & 0.024 \\
\hline \multicolumn{6}{|l|}{ Referral to cardiologists } \\
\hline Yes & $258(33.0 \%)$ & $167(64.7 \%)$ & $91(35.3 \%)$ & Reference & - \\
\hline No & $524(67.0 \%)$ & $374(71.4 \%)$ & $150(28.6 \%)$ & $1.35(0.99-1.87)$ & 0.059 \\
\hline \multicolumn{6}{|l|}{ Participated in educational activities } \\
\hline Yes & $167(21.5 \%)$ & $122(73.0 \%)$ & $45(27.0 \%)$ & Reference & - \\
\hline No & $608(78.5 \%)$ & $415(68.3 \%)$ & $193(31.7 \%)$ & $0.79(0.54-1.16)$ & 0.235 \\
\hline \multicolumn{6}{|l|}{ Drug treatment } \\
\hline Without medications and/or insulin & $57(7.3 \%)$ & $27(47.3 \%)$ & $30(52.7 \%)$ & Reference & - \\
\hline Oral monotherapy & $420(54.0 \%)$ & $273(65.0 \%)$ & $147(35.0 \%)$ & $2.06(1.18-3.60)$ & 0.011 \\
\hline Combined oral therapy & $249(32.0 \%)$ & $197(79.1 \%)$ & $52(20.9 \%)$ & $4.21(2.30-7.69)$ & $<0.001$ \\
\hline Insulin therapy with or without OAD & $52(6.7 \%)$ & $44(84.6 \%)$ & $8(15.4 \%)$ & $6.11(2.45-15.3)$ & $<0.001$ \\
\hline
\end{tabular}

*During the 12 months prior to the interview.

Data reported as mean \pm SD or N (\%). A1c: Glycosylated hemoglobin A; OAD: Oral antidiabetic; FHS: Family Health Strategy; CI: Confidence Interval; BMI: Body Mass Index; OR: Odds Ratio. T-test $<0.05$ for continuous variables and $\chi^{2}$ test $<0.05$ for categorical variables.

The final model showed that variables such as: age in its continuous form, duration of illness, therapeutic regimen, referral to the endocrinologist, and number of contacts with the FHS during the 12 months prior to the interview remained associated with inadequate glycemic control (Table 3). Younger people with DM with a longer duration of the disease, a complex therapeutic regimen involving more than one $\mathrm{OAD}$ (oral antidiabetic) and/or insulin, who were not referred to an endocrinologist during the 12 months prior to the research, and those with more contacts with the FHS in the same period were significantly more likely to have inadequate glycemic control.

Table 3 - Multivariate analysis by logistic regression of the potential predictors of glycemic control (final model) - Recife, PE, Brazil, 2009-2010.

\begin{tabular}{|c|c|c|}
\hline Variables & OR (CI 95\%): & $p$-value \\
\hline Age (in years) & $0.91(0.86-0.97)$ & 0.006 \\
\hline \multicolumn{3}{|l|}{ Duration of illness } \\
\hline$<5$ years & Reference & - \\
\hline From 5 to 9 years & $1.90(1.23-2.92)$ & 0.004 \\
\hline 10 years and longer & $2.32(1.56-3.45)$ & $<0.001$ \\
\hline \multicolumn{3}{|l|}{ Referral to endocrinologists* } \\
\hline Yes & Reference & - \\
\hline No & $1.97(1.30-3.00)$ & 0.001 \\
\hline \multicolumn{3}{|l|}{ Drug treatment } \\
\hline Without medication and/or insulin & Reference & - \\
\hline Oral monotherapy & $2.01(1.11-3.62)$ & 0.020 \\
\hline Combined oral therapy & $3.60(1.89-6.84)$ & $<0.001$ \\
\hline Insulin therapy with or without OAD & $5.12(1.93-13.6)$ & 0.001 \\
\hline
\end{tabular}




\begin{tabular}{lcc}
\multicolumn{1}{c}{ Variables } & OR (CI 95\%): & $\boldsymbol{p}$-value \\
\hline $\begin{array}{l}\text { Number of contacts with the FHS* } \\
\quad 4 \text { times }\end{array}$ & Reference & - \\
$1-3$ times & $0.95(0.64-1.40)$ & 0.790 \\
$\quad$ None & $0.69(0.45-1.04)$ & 0.074
\end{tabular}

OAD: Oral antidiabetic; FHS: Family Health Strategy; CI: Confidence interval; OR: Odds Ratio. *In the 12 months prior to the interview.

\section{DISCUSSION}

The results of this study showed a high prevalence of inadequate glycemic control (69.3\%) among the participants. Similar to other studies conducted in Primary Health Care (PHC) outside Brazil ${ }^{(7-11)}$, younger people with DM were more likely to have inadequate glycemic control. This result may be associated with the fact that older people with DM may be retired, and consequently have more time for self-care and DM monitoring ${ }^{(8)}$. In addition, a behavioral reason can be considered for this result, since older adults are more likely to perform self-monitoring of blood glucose more frequently ${ }^{(12)}$, a behavior that has a positive impact on glycemic control ${ }^{(4)}$. The participants with longer duration of the disease were significantly more likely to have inadequate glycemic control, which can be explained by the progressive evolution characteristic of the disease ${ }^{(3)}$.

The high rate of illiteracy among the studied subjects with DM stands out. The prevalence of inadequate glycemic control was not associated with this variable in the final model, although the results may point to a more adequate control tendency when the level of education increases, corroborating the results of other studies ${ }^{(13-16)}$ which demonstrated that having a higher education level is associated with better glycemic control. One justification for this may be a tendency for people with a higher education level to be more concerned about adhering to the prescribed therapy, as well as to comply with the clinical recommendations proposed by the health team involved ${ }^{(12-13)}$.

The variable of occupation was significantly associated with glycemic control for housewives/students. Other studies $^{(8-9,17)}$ have suggested that having an occupation (represented in the forms of occupation and housewife/student categories) corresponds to a risk factor for the occurrence of inadequate glycemic control. This may be associated with the fact that people with DM that have an occupation have less free time to manage and monitor their illness ${ }^{(8)}$, a justification also applied to housewives and students. It is worth mentioning that interpersonal family stress associated to its role in family conflicts, including daily responsibilities, may also influence glycemic control ${ }^{(18)}$. However, this variable did not remain significant in the multivariate model.

Regarding lifestyle, the frequency of participants who performed some physical activity and declared adopting a healthy diet at the time of the interview was low, considering the importance of these habits for effective glycemic control ${ }^{(4)}$. Although the literature indicates this association between glycemic control and healthy lifestyle, a positive statistical relationship between the variables of this context and glycemic control was not found, and was a result also observed in other studies developed in the $\mathrm{PHC}^{(19)}$.

The BMI variable was inversely related to glycemic control, unlike that found in other studies ${ }^{(5,9,20)}$. The most likely explanation for this result is the understanding of the causal relationship between the explanatory variable and the outcome variable: adequate glycemic control can cause weight gain instead of weight gain improving glycemic control ${ }^{(21-22)}$. It is worth noting that the variable did not remain associated to glycemic control in the multivariate analysis.

Glycemic control, in addition to blood pressure and lipid control, physical activity and nutritional monitoring are important protection factors in relation to complications due to $\mathrm{DM}^{(4)}$. In the present study, the frequency of complications was considerable and superior to that found in other studies $^{(23)}$, and it may reflect the high prevalence of poor glycemic control. However, another explanation may be that these complications were only sought by questions asked of interviewed people with DM, without direct verification of their existence. In addition, respondents were not always able to respond accurately. Corroborating the literature ${ }^{(4,24-25)}$, the present study presented a positive statistical relationship between inadequate glycemic control and the occurrence of DM-related complications, although this variable was not maintained in the final model, perhaps because it was closely linked to the duration of diabetes.

The frequency of participants who had no contact with the FHS during the year prior to the interview was high and reflects the need for changes in relation to the services provided in the context of PHC. People with DM having more contact with FHS were more likely to have inadequate glycemic control; a result found in other studies in the context of $\mathrm{PHC}^{(20)}$. This result suggests that FHS action should be rethought so that participants with adequate glycemic control have a higher frequency of contacts with the health system, thus decreasing the probability of progressing to a clinical picture of inadequate glycemic control.

Participants referred to endocrinologists and cardiologists during the year prior to the interview had a significantly lower probability of having inadequate glycemic control, considering that referral to the former remained in the final regression model. The prescription of treatment as recommended by the guidelines by the specialists may also be one of the justifications for this difference in favor of the specialists in relation to PHC professionals, as well as the experts' greater propensity to request further preventive health examinations such as lipid/cholesterol testing, thereby allowing more frequent evaluation of the metabolic control of people with DM, and making it difficult to progress to an 
inadequate glycemic control ${ }^{(7)}$. But the very fact that $\mathrm{PHC}$ refers people with DM to specialists also points to greater care in the management of these patients, which in itself can positively influence glycemic control.

In the context of FHS activities, although participation in educational activities was shown to be an important indicator of adherence to the therapeutic regimen and benefits in the treatment and control of $\mathrm{DM}^{(26-27)}$, no positive association was found between this variable and the studied outcome variable, and it is important to consider the low frequency of people with DM who reported having participated in some educational activity in the year prior to the interview. This proportion was similar to that found in another study ${ }^{(28)}$, which may justify the absence of this positive association in the present study.

The variable referring to the therapeutic regimen was independently associated with glycemic control, so that people with DM using insulin with or without associated OAD presented a significantly higher probability of having an inadequate glycemic control remaining in the final regression model, and thus corroborating the results found in several studies in the literature ${ }^{(8,10,12,19,29-30)}$. This result was already expected, since insulin is the last resort for DM treatment ${ }^{(4,8)}$. This result must be interpreted in light of one of the major limitations of the analysis, namely the cross-sectional design of the study. Consequently, the most plausible explanation for the relationship found is that inadequate glycemic control leads to therapeutic escalation rather than the opposite, and it should be noted that changes in the regimen mainly reflect the interventions from the prescriber, and do not necessarily result in better glycemic control ${ }^{(21)}$.

\section{CONCLUSION}

We found a greater probability of inadequate glycemic control in younger people with longer duration of DM, having more contacts with the FHS, with fewer referrals to endocrinologists during the 12 months prior to the interview and with more complex pharmacological treatment. These results indicate the need for changes in the actions performed in the FHS context to obtain adequate glycemic control.

Although the determinants of glycemic control and the quality of DM care are multifaceted, complex and result from an interaction of the patient, healthcare and professional aspects involved, the results of this analysis suggest that improvements could come from paying more attention to younger people with DM, by reinforcing health actions in the context of $\mathrm{PHC}$, and by more regularly referring patients to specialists when the need is evident.

Knowledge of these factors and how they act as barriers or facilitators of glycemic control favors accomplishment of appropriate health actions and an elaboration of individualized therapeutic plans, allowing for a collaborative approach centered on the patient aiming to obtain adequate glycemic control, with a subsequent positive impact in terms of socioeconomic costs and quality of life.

\section{RESUMO}

Objetivo: Identificar fatores associados ao controle glicêmico em pessoas com Diabetes Mellitus (DM) tipo 2 cadastradas na Estratégia Saúde da Família (ESF) em Pernambuco, Brasil. Método: Foram investigadas, por regressão múltipla, as associações entre o controle glicêmico (hemoglobina A glicosilada menor ou maior ou igual a 7\%) apresentado pelas pessoas com DM e variáveis relacionadas com condições sociodemográficas, hábitos de vida, características do diabetes, de seu tratamento e acompanhamento dos pacientes pelos serviços de saúde. Resultados: Mais de 65\% dos participantes apresentaram controle glicêmico inadequado, principalmente aqueles com idade menor, duração da doença mais longa, mais contatos anuais com a ESF e regime terapêutico complexo. Pessoas com DM sem encaminhamentos para especialistas apresentaram um maior descontrole glicêmico. Associações com escolaridade e obesidade não permaneceram significativas no modelo multivariado. Conclusão: A evolução do diabetes dificulta o controle adequado, todavia, a atenção às pessoas com DM mais jovens e os encaminhamentos para especialistas são fatores suscetíveis de melhora do controle glicêmico.

\section{DESCRITORES}

Diabetes Mellitus Tipo 2; Atenção Primária à Saúde; Hemoglobina A Glicosilada; Estratégia Saúde da Família.

\section{RESUMEN}

Objetivo: Identificar los factores asociados con el control glucémico en personas con Diabetes Mellitus (DM) tipo 2 registradas en la Estrategia Salud de la Familia (ESF) en Pernambuco, Brasil. Método: Fueron investigadas, por regresión múltiple, las asociaciones entre el control glucémico (hemoglobina A glicosilada menor o mayor o igual al 7\%) presentado por las personas con DM y variables relacionadas con condiciones sociodemográficas, hábitos de vida, características de la diabetes, de su tratamiento y seguimiento de los pacientes por los servicios sanitarios. Resultados: Más del 65\% de los participantes presentaron control glucémico inadecuado, especialmente aquellos de menos edad, duración de la enfermedad más larga, más contactos anuales con la ESF y régimen terapéutico complejo. Personas con DM sin derivaciones a especialistas presentaron un mayor descontrol glucémico. Asociaciones con escolaridad y obesidad no permanecieron significativas en el modelo multivariado. Conclusión: La evolución de la diabetes dificulta el control adecuado. Sin embargo, la atención a las personas con DM más jóvenes y las derivaciones a especialistas son factores susceptibles de mejora del control glucémico.

\section{DESCRIPTORES}

Diabetes Mellitus Tipo 2; Atención Primaria de Salud; Hemoglobina A Glucosilada; Estrategia de Salud Familiar.

\section{REFERENCES}

1. Schmidt MI, Duncan BB, Azevedo e Silva G, Menezes AM, Monteiro CA, Barreto SM, et al. Chronic non-communicable diseases in Brazil: burden and current challenges. Lancet 2011;377(9781):1949-61.

2. Shaw JE, Sicree RA, Zimmet PZ. Global estimates of the prevalence of diabetes for 2010 and 2030. Diabetes Res Clin Pract 2010;87(1):4-14. 
3. Brasil. Ministério da Saúde; Secretaria de Vigilância em Saúde. Vigitel Brasil 2013: vigilância de fatores de risco e proteção para doenças crônicas por inquérito telefônico. Brasília: MS; 2014.

4. Sociedade Brasileira de Diabetes. Diretrizes 2015-2016. São Paulo: AC Farmacêutica; 2016.

5. Luijks H, Biermans M, Bor H, Weel CV, Lagro-Janssen T, Grauw W, et al. The effect of comorbidity on glycemic control and systolic blood pressure in type 2 diabetes: a cohort study with 5 year followup in primary care. PLoS One 2015;10(10):e138662.

6. Fontbonne A, Cesse EAP, Sousa IM, Souza WV, Chaves VL, Bezerra AF, et al. Risk factor control in hypertensive and diabetic subjects followed by the Family Health Strategy in the state of Pernambuco, Brazil - SERVIDIAH Study. Cad Saúde Pública. 2013;29(6):1195-204.

7. Bajaj HS, Aronson R, Venn K, YC, Sharaan ME. The need associated with diabetes primary care and the impact of referral to a SpecialistCentered Multidisciplinary Diabetes Program (the NADIR Study). Can J Diabetes. 2016;40(2):120-5.

8. Ahmad B, Khalid BA, Zaini A, Hussain NA, Quek KF. Influencing factors of glycaemic control in patients attending different types of urban health care settings in Malaysia. Diabetes Res Clin Pract. 2011;93(1)e:12-4.

9. Raum E, Krämer HU, Rüter G, Rothenbacher D, Rosemann T, Szecsenyi J, et al. Medication non-adherence and poor glycaemic control in patients with type 2 diabetes mellitus. Diabetes Res Clin Pract. 2012;97(3):377-84.

10. Crowley MJ, Holleman R, Klamerus ML, Bosworth HB, Edelman D, Heisler M. Factors associated with persistent poorly-controlled diabetes mellitus (PPDM): clues to improving management in patients with resistant poor control. Chronic Illn. 2014;10(4):291-302.

11. Pablo Moreno A, Santiago Pérez MI, Abraíra Santos V, Aréjula Torres JL, Díaz Holgado A, Gandarillas Grande A, et al. Control de la diabetes mellitus en población adulta según las características del personal de enfermería de atención primaria de la comunidad de Madrid: análisis multinivel. Rev Esp Salud Pública. 2016;90(4):1-13.

12. Janghorbani M, Amini M. Patterns and predictors of long-term glycemic control in patients with type 2 diabetes. ISRN Endocrinol. 2012:526824.

13. Al-Qazaz HK, Sulaiman SA, Hassali MA, Shafie AA, Sundram S, Al-Nuri R, et al. Diabetes knowledge, medication adherence and glycemic control among patients with type 2 diabetes. Int J Clin Pharm. 2011;33(6):1028-35.

14. Otiniano ME, Snih SA, Goodwin JS, Ray L, Ghatrif MA, Markides K S. Factors associated with poor glycemic control in older mexican american diabetics aged 75 years and older. J Diabetes Complications. 2012;26(3):181-6.

15. Walker RJ, Gebregziabher M, Martin-Harris B, Egede LE. Independent effects of socioeconomic and psychological social determinants of health on self-care and outcomes in type 2 diabetes. Gen Hosp Psychiatry. 2014;36(6):662-8.

16. Houle J, Lauzier-Jobin F, Beaulieu MD, Meunier S, Coulombe S, Côté J, et al. Socioeconomic status and glycemic control in adult patients with type 2 diabetes: a mediation analysis. BMJ Open Diabetes Res Care. 2016;14(1):e000184.

17. Tong WT, Vethakkan SR, Ng CJ. Why do some people with type 2 diabetes who are using insulin have poor glycaemic control? A qualitative study. BMJ Open 2015;5(1):e006407.

18. Silva DMGV, Hegadoren K, Lasiuk G. As perspectivas de donas de casa brasileiras sobre a sua experiência com diabetes mellitus tipo 2. Rev Latino Am Enfermagem. 2012;20: 1-9.

19. Kellow NJ, Savigel GS, Khalil H. Predictors of poor glycaemic control during the initial five years post-diagnosis in rural adults with type 2 diabetes. Aust J Rural Health. 2011;19(5): 267-74.

20. Toh MPHS, Wu CX, Leong HSS. Association of younger age with poor glycemic and cholesterol control in Asians with type 2 diabetes mellitus in Singapore. J Endocrinol Metab. 2011;1(1):27-37.

21. Nichols GA, Hillier TA, Javor K, Brown JB. Predictors of glycemic control in insulin-using adults with type 2 diabetes. Diabetes Care. 2000;23(3):273-7.

22. Assunção MCF, Santos IS, Valle NCJ. Blood glucose control in diabetes patients seen in primary health care centers. Rev Saúde Pública. 2005;39(2):183-90.

23. Mendes ABV, Fittipaldi JAS, Neves RCS, Chacra AR, Moreira Junior ED. Prevalence and correlates of inadequade glycaemic control: results from a nationwide survey in 6.671 adults with diabetes in Brazil. Acta Diabetol. 2010;47(2):137-45.

24. Sanal TS, Nair NS, Adhikari P. Factors associated with poor control of type 2 diabetes mellitus: a systematic review and meta-analysis. J Diabetol [Internet]. 2011 [cited 2016 Apr 21]. Available from: http://www.journalofdiabetology.org/Pages/Releases/FullTexts/Sixthlssue/ RA-1-JOD-11-007.aspx

25. Gorst C, Kwok CS, Aslam S, Buchan I, Kontopantelis E, Myint PK, et al. Long-term glycemic variability and risk of adverse outcomes: a systematic review and meta-analysis. Diabetes Care. 2015;38(12):2354-69.

26. Maia MA, Reis IA, Torres HC. Relationship between the users' contact time in educational programs on diabetes mellitus and self-care skills and knowledge. Rev Esc Enferm USP. 2016;50(1):59-64. DOI: http://dx.doi.org/10.1590/S0080-623420160000100008

27. Huxley C, Sturt J, Dale J, Walker R, Caramlau I, O'Hare JP, et al. Is it possible to predict improved diabetes outcomes following diabetes self-management education: a mixed-methods longitudinal design. BMJ Open. 2015;5(11):e008781.

28. Moreira Junior ED, Neves RC, Nunes ZO, Almeida MCC, Mendes ABV, Fittipaldi JAS, et al. Glycemic control and its correlates in patients with diabetes in Venezuela: results from a nationwide survey. Diabetes Res Clin Pract. 2010;87(3):407-14.

29. Lin SD, Tsai ST, Tu ST, Su CC, Chen JF, Lu CH, et al. Glycosylated hemoglobin level and number of oral antidiabetic drugs predict whether or not glycemic target is achieved in insulin-requiring type 2 diabetes. Prim Care Diabetes. 2015;9(2):135-41.

30. Alonso-Fernández M, Mancera-Romero J, Mediavilla-Bravo JJ, Comas-Samper JM, López-Simarro F, Pérez-Unanua MP, et al . Glycemic control and use of A1c in primary care patients with type 2 diabetes mellitus. Prim Care Diabetes 2015;9(5):385-91.

Financial support: Conselho Nacional de Desenvolvimento Científico e Tecnológico (CNPq). Process number 576677/2008-6. Fundação de Amparo à Ciência e Tecnologia do Estado de Pernambuco, Process number APQ 1378-4.00/08. Fundação Oswaldo Cruz. PAPES V. Process number 403640/2008-3. Institut de Recherche pour le Développement. Convênio CNPq-IRD. Process number 490855/2008-3. 